\title{
"Pemanfaatan Media Digital dalam Pemasaran Produk di Masa Pandemi" pada Ibu-Ibu PKK RW 05 Cisauk Kabupaten Tangerang
}

\author{
Hasti Istifara ${ }^{1}$, Devi Ratna Purwanti ${ }^{2}$, Aditya Syaathir Nuraziz ${ }^{3}$ Ilfa Aulia Hakim ${ }^{4}$, \\ Sy Hasiba Aisyah M Almusawa ${ }^{5}$, Aditya Erlangga ${ }^{6}$ \\ ${ }^{123456}$ Program Studi Manajemen, Universitas Pamulang, Tangerang Selatan \\ deviratnapurwati@gmail.com²*
}

Received 16 April 2021| Revised 18 April 2021 | Accepted 24 April 2021

*Korespondensi Penulis

\begin{abstract}
Abstrak
Tujuan pengabdian Kepada Masyarakat (PKM) Mahasiswa ini adalah untuk memberikan pengetahuan dan pemahaman kepada Ibu-ibu PKK Rw 05 Cisauk Kabupaten Tangerang . Adapun Metode kegiatan ini adalah mendatangi Pusat kegiatan Ibu-Ibu PKK RW 05 tersebut dan memberikan pelatihan serta diskusi mengenai cara berjualan online di masa pandemi covid-19. Hasil dari kegiatan tersebut adalah para peserta menjadi lebih mengerti makna berjualan online di masa pandemi covid -19. Sehingga kedepannya ibu-ibu PKK mengerti cara berjualan online.
\end{abstract}

Kata Kunci: Berwirausaha

\begin{abstract}
The purpose of this Student Community Service (PKM) is to provide knowledge and understanding to PKK Rw 05 Cisauk mothers in Tangerang Regency. The method of this activity is to visit the PKK RW 05 women activity center and provide training and discussion on how to sell online during the Covid19 pandemic. The result of this activity was that the participants understood better the meaning of selling online during the Covid-19 pandemic. So that in the future PKK mothers will understand how to sell online.
\end{abstract}

\section{Keywords: Entrepreneurship}

\section{PENDAHULUAN}

Masa pandemi Covid-19, perekonomian di Indonesia sangat menurun drastis, sehingga banyak sekali para karyawan yang di PHK. Pendapatan para pekerja baik karyawan maupun pengusaha menurun, dikarenakan banyaknya perusahaan yang tidak mampu untuk membayar gaji para karyawan dikarenakan lesunya perekonoian dan kurangnya daya beli msayarakat yang disebabkan oleh adanya pandemi Covid-19. Pemberlakukan peraturan PSBB (Pembatasan Sosial Berskala Besar) oleh pemerintah akan berdampak pada ekonomi masyarakat. Walaupun diperkirakan dampaknya tidak terlalau besar, tetapi PSBB tetap saja membuat berat bagi para pekerja, terutama pedagang offline. Karenanya diperlukan perencanaan keuangan yang bagi bagi masyarakat dalam mengatasinya (G.Kusjono, dkk: 2021).

Meski berat, kalangan dunia usaha mendukung PSBB disetiap wilayah, demi menekan perkembangan virus corona. Pemberlakuan PSBB dakui memberikan dampak yang kurang baik bagi para pekerja, dikarenakan secara tidak langsung dampaknya sangat terasa karena sebagian para pekerja dirumahkan sebab ketidak mampuan perusahaan untuk tetap mempertahankan para karyawannya yang diakibatkan adanya pandemi dan kebijakan PSBB. 
Solusi yang di ambil bagi para pekerja yang mengalami PHK dari dampak adanya pandemi ini membuat mereka harus bisa untuk tetap berpenghasilan dengan mencari peluang lain salah satunya adalah dengan membuka usaha dengan memanfaatkan media sosial dan ecommerce. Untuk memasarkan produk yang akan mereka jual, para pengusaha dapat membentuk tim dengan reseller, dropship atau yang lainnya untuk menjual produk mereka ke masyarakat luas.

Fokus masalah dalam kegiatan PKM ini adalah bagaimana terbangunnya kesadaran setiap anggota masyarakat untuk berjualan/ berwirausaha agar mampu menciptakan dan menjual berbagai macam barang dan jasa. Masyarakat yang dimaksud adalah masyarakat yang berada di lingkungan RW 05 Cisauk Kabupaten Tangerang.

Adapun tujuan dilakukannya Pengabdian Kepada Masyarakat (PKM) yaitu sebagai berikut:

1. Memberikan pengetahuan dan pengarahan kepada ibu-ibu RW05 Cisauk Kabupaten Tangerang mengenai berjualan via online.

2. Membangun dan menyakini kepada ibu-ibu RW 05 Cisauk Kabupaten Tangerang terhadap peluang masa depan yang cerah.

3. Memberikan semangat dan motivasi bagi para ibu-ibu RW 05 Cisauk Kabupaten Tangerang dalam menanam jiwa berwirausaha dilingkungan masyarakat.

Manfaat yang diperoleh Pengabdian Kepada Masyarakat (PKM) ini dapat dijelaskan sebagai berikut:

1. Manfaat bagi peserta

Para peserta menjadi sadar akan pentingnya berwirausaha dilikungan masyarakat sehingga dapat mengembangkan dan menerapkan jiwa wirausaha dalam kehidupan sehari-hari dan membuat inovasiinovasi baru sehingga memiliki kemampuan bersaing yang lebih baik. Kemudian para peserta menjadi tumbuh minat untuk mau dan terampil dalam mengembangkan wirausaha dilingkungan masyarakat. Selain itu, kegiatan ini dapat membantu peserta untuk menghasilkan penghasilan sendiri.
2. Manfaat akademik

Bagi pihak akademik dengan adanya kegiatan pengabdian kepada masyarakat secara tidak langsung dapat menjadi bahan referensi untuk membantu mahasiwa/i lainnya yang akan menyusun laporan ini.

3. Manfaat bagi mahasiswa

Dapat membangun mental memotivasi, mengasah kreatifitas dalam pelatihan, melahirkan rasa percaya diri untuk menyampaikan hal-hal yang positif, dan mendapatkan pengalaman dalam pengabdian kepada masyarakat.

4. Manfaat bagi masyarakat

Dengan adanya program penyuluhan ini semoga dapat membangun mental berbisnis yang kreatif dan inovatif sehingga dapat menciptakan lapangan pekerjaan untuk masyarakat sekitar dan mengurangi tingkat pengangguran.

\section{Kajian Teori}

Media digital adalah media yang dikodekan dalam format yang dapat dibaca oleh mesin (machine-readable). Konsep Media Digital adalah biner yaitu 0 dan 1 menggunakan gelombang diskrit. Media digital dapat dibuat, dilihat, didistribusikan, dimodifikasi dan bisa bertahan pada perangkat elektronik digital. Proses digital menggunakan logika Algoritma. Program-program komputer dan perangkat lunak seperti citra digital, digital video video games; halaman web dan situs web, termasuk media sosial; data dan database; digital audio, seperti mp3, mp4 dan e-buku adalah contoh media digital. Media digital sangat berbeda dengan media analog yang mengandalkan sistem manual seperti media cetak, buku cetak, surat kabar dan majalah yang masih bersifat tradisional seperti gambar, film tape audio dan lain-lain.

Dalam era modern kombinasi antara Internet dan komputasi personal, menyebabkan media digital membawa dampak dan masalah dalam dunia penerbitan, jurnalistik, hiburan, pendidikan, perdagangan dan politik. Media Digital juga telah menimbulkan tantangan baru terutama bagi hukum yang melindungi hak cipta 
dan kekayaan intelektual, dalam gerakan konten terbuka di mana pencipta konten dengan sukarela menyerahkan sebagian atau seluruh hak-hak hukum mereka untuk pekerjaan mereka. Kini Media digital sudah memasuki sendi-sendi kehidupan masyarakat dan dampaknya telah terasa bagi masyarakat luas dan itu menunjukan bahwa media digital adalah awal sebuah era baru dalam sejarah industri yang disebut era Informasi, dan telah mengarah ke masyarakat paperless di mana semua produk informasi pada media yang diproduksi dan dikonsumsi berbasis komputer. Namun, tantangan menuju transisi media digital, termasuk produk undang-undang yang mengatur hak cipta, sensor, digital divide, adalah momok menuju era kegelapan digital (digital dark age) di mana media yang lebih tua menjadi tidak dapat diakses ke sistem baru atau tidak bisa diupgrade ke sistem informasi. Sedangkan media-media Digital yang signifikan, luas dan kompleks telah memberi dampak pada masyarakat dan budayanya.

Menurut Kotler \& Amstrong (2012) Ecommerce adalah saluran online yang dapat dijangkau seseorang melalui komputer, yang digunakan oleh pebisnis dalam melakukan aktifitas bisnisnya dan digunakan konsumen untuk mendapatkan informasi dengan menggunakan bantuan komputer yang dalam prosesnya diawali dengan memberi jasa informasi pada konsumen dalam penentuan pilihan. Menurut Wong (2010) e-commerce adalah proses jual beli dan memasarkan barang serta jasa melalui sistem elektronik, seperti radio, televisi dan jaringan komputer atau internet. Maka dapat disimpulkan bahwa ecommerce merupakan kumpulan dinamis antara teknologi, aplikasi dan proses bisnis yang menghubungkan perusahaan dan konsumen serta komunitas tertentu dimana pertukaran barang antara pengecer dan konsumen dari berbagai komoditi dalam skala luas dan suatu transaksi elektronik, dan dalam proses pengiriman barang dari pengecer menggunakan transportasi dari suatu wilayah ke wilayah lain hingga sampai ke tangan konsumen dan hubungan yang terjadi adalah hubungan yang saling menguntungkan kedua belah pihak.

Saat ini, persaingan marketplace yang ada di Indonesia sangat ketat. Banyak sekali pemain baru dan pemain lama yang bersaing dalam mendapatkan konsumen di Indonesia. Marketplace di bawah ini merupakan contoh lima marketplace besar di Indonesia yang termasuk dalam jenis marketplace murni, alasannya adalah jangkauan pasarnya lebih banyak dan sangat beragam.

1. Tokopedia

Didirikan oleh William Tanuwijaya pada Februari 2009, Tokopedia merupakan salah satu marketplace yang sudah bergerak lama di Indnonesia. Marketplace ini bahkan mendapat predikat sebagai marketplace terbesar dengan jumlah kunjungan perbulan sebanyak 137.200.900 pengunjung. Selain itu, tokopedia juga termasuk ke dalam kategori salah satu startup unicorn Indonesia, yang artinya nilai valuasi Tokopedia sudah menyentuh angka lebih dari \$1 miliyar.

2. Bukalapak

Posisi kedua dipegang oleh Bukalapak yang sama-sama memiliki gelar startup unicorn layaknya Tokopedia. Bukalapak ini didirikan oleh Ahmad Zaky pada pada 2010 di Bandung, Jawa Barat. Selama ini, marketplace bukalapak sudah berhasil mengumpulkan 115.256.600 pengunjung perbulan di awal tahun 2019 lalu.

3. Shopee

Shopee merupakan salah satu marketplace asal Singapura, marketplace ini sudah mengekspansi pasar Asia Tenggara sejak tahun 2015 lalu, termasuk ke Indonesia. Setelah empat tahun melakukan ekspansi, akhirnya shopee berhasil menduduki posisi marketplace terbesar ketiga di Indonesia. Kunjungan bulanan yang ada pada situs marketplace ini menyentuh angka 74.995.300. Marketplace yang termasuk ke dalam SEA Group ini mampu mencuri perhatian publik Indoneisa dengan berbagai kampanye iklan kreatif, 
termasuk melibatkan selebritas Korea Selatan, Blackpink.

4. Lazada

Nampaknya Lazada mulai merasa kesulitan dalam menghadapi persaingan dengan marketplace lainnya. Walaupun pada tahun 2018 lalu marketplace ini mendapati banyak sekali pengunjung, namun pada tahun 2019 tahun lalu Lazada hanya mampu menduduki peringkat keempat dengan jumlah pengunjung 52.044.500 per bulan.

5. Blibli

Bli-bli merupakan marketplace karya PT Global Digital Niaga, salah satu anak perusahaan Djarum. Marketplace ini mampu menduduki peringkat kelima dengan jumlah total pengunjung bulanan sebanyak 32.597.200.

Dari beberapa contoh di atas, kelompok kami mengambil satu contoh yaitu Shoppe.Di Indonesia merupakan salah satu negara dengan trend belanja Online yang sangat di gemari konsumen, yaitu dapat dilihat dengan bermuculan aplikasi-aplikasi Onlineshoping yang salah satuya adalah Shopee. Di aplikasi ini konsumen dapat menemukan berbagai macam trend fashion sesuai kategori yang dibutuhkan seperti berupa fashion, tas, sepatu, baju bayi, aksesoris, handphone dan lain sebagainya baik produk lokal maupun produk internasional, hal ini menjadikan konsumen Indonesia dengan mudah menerima perkembangan secara positif.

Munculnya aplikasi ini memberikan kemudahan bagi konsumen untuk membeli produk karena hanya dengan melalui smartphone konsumen bisa berbelanja lalu barang akan diantar oleh kurir. Selain itu, kemudahan lainnya adalah konsumen bisa membandingkan harga, membandingkan dari segi spesifikasi produk dan kemudahan memesan barang dari toko Online manapun. Konsumen bisa menanyakan lebih terperinci kepada penjual melalui obrolan (chatting) yang sudah disediakan oleh aplikasi Shopee. Dan setelah konsumen menanyakan ketersediaan produk ke penjual langkah selanjutnya adalah melakukan transfer melalui Indomaret, Alfamart, Bank ataupun dengan sistem COD (Cash On Delivery) jika di toko Online tersebut menyediakan sistem itu.

Web Shopee telah memberikan fasilitas kepada konsumen dalam keamanan bertransaksi karena di aplikasi Shopee terdapat gratis ongkir keseluruh Indonesia dengan ketentuan tertentu, dan garansi uang kembali apabila produk tidak sesuai dengan keinginan dan Shopee juga jelas dalam merinci dalam proses pembayaran sampai pengiriman barang hingga barang sampai pada konsumen sesuai harapan. Hal demikian dapat menimbulkan Kepercayaan bahwa barang atau produk yang dibeli dapat dipastikan keamanan nya, dan apabila barang yang dipesan konsumen belum sampai pada konsumen sesuai waktu yang tertera di aplikasi maka konsumen bisa mengajukan pengembalian dana sehingga konsumen merasa tidak akan dirugikan saat melakukan pembelian di aplikasi Shopee.

Konsumen bisa melihat komentarkomentar yang sudah pernah membeli produk tersebut dengan memunculkan tanda bintang dan beberapa komentar mengenai produk yang sudah pernah mereka beli dan ini bisa berpengaruh penting untuk pembeli baru dalam melakukan Keputusan Pembelian. Sehingga Kualitas Informasi, Kemudahan dan Kepercayaan dapat mempertimbangkan Keputusan Pembelian secara Online di situs Shopee. Kehadiran yang beraneka macam bisnis di perdagangan Online menjadi suatu tantangan bagi pembisnis lama untuk mengikuti selera konsumen, mempertahankan eksistensinya dan mampu melihat peluang serta memanfaatkannya. Dengan strategi dan konsep yang baik diharapkan situs Shopee dapat menarik konsumen lebih banyak lagi untuk berbelanja melalui situs web tersebut.

\section{METODE}

Dalam kegiatan ini kami mendatangin langsung Ibu-Ibu PKK RW 05 Cisauk Kabupaten Tangerang dan memberikan pembelajaran serta diskusi mengenai tips berjualan via online dengan metode presentasi materi menggunakan proyektor. Solusi yang 
diperoleh dari kegiatan PKM disesuaikan dengan permasalahan yang dihadapi oleh para peserta ibu-ibu PKK pada Balai pertemuan RW

05. Adapun solusi tersebut meliputi :

Tabel 1. Permasalahan dan solusi

\begin{tabular}{llll}
\hline No & Peserta & Permasalahan & Solusi \\
\hline 1 & pada Ibu-ibu PKK & Beberapa ibu-ibu masih belum & Memberikan penyuluhan dan pelatihan \\
Rw 05 Cisauk & memahami bagaimana pemanfaat bagaimana memanfaatkan media digital \\
Kabupaten & media digital dalam memasarkan untuk memasarkan produk secara online \\
Tangerang & produk secara online atau e- atau e-commerce \\
& commerce & \\
\cline { 2 - 4 } & Sebagian ibu-ibu masih belum Memberikan arahan bagaimana cara untuk \\
& memahami bagaimana mendaftar mendaftar dan memasarkan produk ke \\
& dan memasarkan produknya ke dalam marketplace Shopee \\
& dalam marketplace salah satunya \\
& Shopee & \\
\hline
\end{tabular}

Pemberian solusi ini didasarkan pada pemahaman dan keterampilan dari para Ibu-ibu PKK dalam pemahaman memasarkan produk secara dengan menggunakan media digital, untuk keperluan usaha atau mengembangkan usaha yang sudah berjalan dengan memanfaatkan kemajuan teknologi.

\section{HASIL DAN PEMBAHASAN}

Berjualan secara online di tengah pandemic cobid-19 ini sangatlah efisien untuk bisa mempertahankan perekonomian ibu-ibu rumah tangga, dan membuat ibu-ibu bisa menjadi lebih bermotivasi dan berwawasan kedepannya.

Marketplace merupakan platform peranta ra yang bertugas menghubungkan pihak pembeli dan penjual. Sementara itu, online shop merupakan situs pribadi milik perusahaan yang di dalamnya melakukan penjualan tanpa perantara. Setiap penjual atau perusahaan bisa membuat online shopnya sendiri sebagai wujud platform yang digunakan untuk menjual produknya secara langsung pada para pembeli.

Perbedaan antar kedua platform ini adalah tersedia atau tidaknya peran perantara. Penjual bisa melakukan penjualan di marketplace dan memiliki website online shop sendiri secara bersamaan serta bisa menganggap bahwa website online shop adalah toko pusat, dan marketplace adalah toko cabang penjual.

\section{SIMPULAN}

Berdasarkan kegitan PKM yang telah dilaksanakan oleh Mahasiswa Program Studi Manajemen Universitas Pamulang dapat disimpulkan:

1. Berjualan via online di tengah pandemic cobid-19 ini sangatlah efisien untuk bisa mempertahankan perekonomian ibu-ibu rumah tangga dan menjadikannya termotivasi dan berwawasan usaha ke depannya.

2. Peserta bisa melakukan penjualan di marketplace dan memiliki website online shop sendiri secara bersamaan serta bisa menganggap bahwa website online shop adalah toko pusat, dan marketplace adalah toko cabang penjual.

\section{DAFTAR PUSTAKA}

Kusjono, G., Sunanto, S., Azwina, D., Sulistyani, T., \& Lesmono, M. A. (2021). Pelatihan Manajemen Keuangan Sebagai Upaya Meningkatkan Daya Saing UMKM Kelurahan Benda Baru Pamulang. JPKM-Aphelion (Jurnal Pengabdian Kepada MasyarakatAphelion), 1(2), 224-233. 
https://accurate.id/marketing-manajemen/apaitu-marketplace/

https://media.neliti.com/media/publications/957

$59-$

https://genie.shop/?utm_source=Googleads\&ut m_medium $=$ cpc\&utm_campaign $=\mathrm{NYM}$ Genie_ID_WEB_NA_Click_CPARegister_Manual_GenieFeature-OWComputer20201110\&adgroup=OmniChannel\&gcli $\mathrm{d}=$ Cj0KCQiAs5eCBhCBARIsAEhk4r6Z VgtpO97CL0CX65qcXVPK3UMK_W O4q10F7QrTODJQf8HXoXgjzwaAvVz EALw_wcB

https://megapolitan.kompas.com/read/2020/12/ 23/12265781/kisah-karyawan-di-phkkarena-covid-19-sulit-dapat-pekerjaanbaru-hingga?page $=$ all 